\title{
Novel Mutation in Bernard-Soulier Syndrome
}

\author{
Kirstin Sandrock $^{\mathrm{a}} \quad$ Ralf Knöfler $^{\mathrm{b}} \quad$ Andreas Greinacher $^{\mathrm{c}}$ Birgitt Fürll ${ }^{\mathrm{c}}$ Sebastian Gerisch ${ }^{\mathrm{a}}$ \\ Ulrich Schuler $^{d}$ Siegmund Gehrisch ${ }^{e}$ Anja Busse ${ }^{a}$ Barbara Zieger ${ }^{a}$
}

${ }^{a}$ Department of Pediatrics and Adolescent Medicine, University of Freiburg, Freiburg i.Br.,

${ }^{\mathrm{b}}$ Department of Pediatrics and Adolescent Medicine, University Hospital Carl Gustav Carus Dresden,

' Institute for Immunology and Transfusion Medicine, Ernst-Moritz-Arndt-University, Greifswald,

${ }^{\mathrm{d}}$ Medical Clinic I, Medical Faculty of Technical University, Dresden,

${ }^{\mathrm{e}}$ Institute of Clinical Chemistry and Laboratory Medicine, Medical Faculty of Technical University, Dresden, Germany

\section{Keywords}

Bernard-Soulier syndrome - Bleeding complications . Thrombocytopenia - Platelet glycoprotein Ib/IX .

Genetic abnormalities · Flow cytometry · Novel deletion

\section{Summary}

Background: Bernard-Soulier syndrome (BSS) is a severe congenital bleeding disorder characterized by thrombocytopenia, thrombocytopathy and decreased platelet adhesion. BSS results from genetic alterations of the glycoprotein (GP) Ib/IX/V complex. Methods: We report on a patient demonstrating typical BSS phenotype (thrombocytopenia with giant platelets, bleeding symptoms). However, BSS was not diagnosed until he reached the age of 39 years. Results: Flow cytometry of the patient's platelets revealed absence of GPIb/IX/V receptor surface expression. In addition, immunofluorescence analysis of patient's platelets demonstrated very faint staining of GPIX. A novel homozygous deletion comprising 11 nucleotides starting at position 1644 of the GPIX gene was identified using molecular genetic analysis. Conclusions: The novel 11-nucleotide deletion (g.1644_1654del11) was identified as causing the bleeding disorder in the BSS patient. This homozygous deletion includes the last 4 nucleotides of the Kozak sequence as well as the start codon and the following 4 nucleotides of the coding sequence. The Kozak sequence is a region indispensable for the initiation of the protein translation process, thus preventing synthesis of functional GPIX protein in the case of deletion.

\section{Schlüsselwörter}

Bernard-Soulier-Syndrom · Blutungssymptome . Thrombozytopenie - Glykoprotein Ib/IX . Genetische Anomalie · Neue Deletion

\section{Zusammenfassung}

Hintergrund: Das Bernard-Soulier-Syndrom (BSS) ist eine angeborene Blutungsstörung, die mit Thrombozytopenie, Thrombozytopathie und verminderter Thrombozytenadhäsion assoziiert ist. BSS wird durch genetische Veränderungen des Glykoprotein(GP)-Ib/IX/V-Komplexes verursacht. Methoden: Wir berichten über einen Patienten mit typischem BSS-Phänotyp (Thrombozytopenie mit Riesenthrombozyten, Blutungssymptome). Dennoch wurde die Diagnose BSS erst im Alter von 39 Jahren gestellt. Ergebnisse: Die Durchflusszytometrie der Thrombozyten des Patienten ergab eine fehlende Oberflächenexpression des GPIb/IX/V-Rezeptors. Zusätzlich zeigten Immunfluoreszenz-Analysen der Thrombozyten eine nur sehr schwache Anfärbung von GPIX. In der molekulargenetischen Analyse wurde eine noch nicht bekannte homozygote Deletion von 11 Nukleotiden (beginnend an Position 1644 im GPIX-Gen) identifiziert. Schlussfolgerungen: Diese neue Deletion von 11 Nukleotiden (g.1644_1654del11) wurde als Ursache für die vermehrte Blutungsneigung bei dem BSS-Patienten identifiziert. Von der homozygoten Deletion betroffen sind die letzten 4 Nukleotide der Kozak-Sequenz sowie das Startkodon und weitere 4 Nukleotide des kodierenden Bereichs. Die Kozak-Sequenz ist unerlässlich für die Initiation der Translation in der Proteinbiosynthese, so dass die bei dem Patienten nachgewiesene Deletion die Synthese des funktionellen GPIX-Proteins verhindert.

\section{KARGER}

Fax +497614520714

Information@Karger.de

www.karger.com (c) 2010 S. Karger GmbH, Freiburg

Accessible online at:

www.karger.com/tmh
Prof. Dr. Barbara Zieger

Zentrum für Kinder- und Jugendmedizin

Universitätsklinikum Freiburg

Mathildenstraße 1, 79106 Freiburg, Germany

Tel. +49 761 270-4300 Fax -4582

barbara.zieger@uniklinik-freiburg.de 


\section{Introduction}

The basic diagnostic criteria for Bernard-Soulier syndrome (BSS) are thrombocytopenia with giant platelets, decreased von Willebrand factor(VWF)-dependent platelet adhesion to the subendothelium, and autosomal recessive inheritance. BSS has an estimated prevalence of one in a million live births. Hallmark of the disease is an aberrant platelet attachment to the vessel wall due to quantitative or qualitative defects of the glycoprotein (GP) Ib/IX/V complex [1]. Physiologically, VWF and its platelet surface receptor GPIb/IX/V play a critical role in hemostasis by initiating thrombus formation and arrest of platelets at the site of vascular injury [2]. Clinically, BSS typically presents with epistaxis, petechiae, or gingival bleeding in infancy. The onset of the disease can vary. Later symptoms usually include menorrhagia, gastrointestinal or genitourinary bleeding. Trauma or surgical procedures especially in mucosal regions may also lead to excessive bleeding. The severity of bleeding symptoms varies substantially among patients [3]. Bleeding time may range from borderline normal up to significantly prolonged. Platelet counts can be within normal limits or severely decreased [4]. Laboratory hallmark are giant platelets, impaired platelet agglutination after stimulation with ristocetin, and normal platelet aggregation with other agonists. GPIb/IX/V surface expression can be decreased or absent, or the function of GPIb/IX/V can be reduced $[5,6]$.

The products of 4 distinct genes ( $G P I b \alpha, G P I b \beta, G P I X$, $G P V$ ) assemble within the maturing megakaryocytes to form the GPIb/IX/V complex in a 2:2:2:1 stochiometry as present in the platelet membrane $[1,7,8]$. GPIb $\alpha, G P I b \beta$ and $G P I X$ are closely associated and are all required for efficient biosynthesis of the platelet receptor. Mutations within GPIb $\alpha, G P I b \beta$ and GPIX mostly prevent constitution and/or trafficking of the complex through the Golgi apparatus and endoplasmic reticulum [1]. GPV is more loosely associated with the complex, and no case of BSS has been reported with a genetic defect in the GPV gene [9]. So far, about 50 genetic causes for BSS have been described mostly affecting GPIb $\alpha$. However, most European patients are affected by mutations in GPIX (table 1). Interestingly, GPIX gene defects are mainly missense mutations leading to single amino acid substitutions. Only one 9-nucleotide deletion in GPIX was described leading to an amino acid substitution (D86A) followed by the deletion of amino acids 87-89 [10]. Here, we report on a patient with a novel homozygous 11-nucleotide deletion within exon 3 of $G P I X$ which is associated with a severe BSS phenotype.

\section{Patients, Material and Methods}

\section{Patient}

The male patient suffered from recurrent epistaxis, easy bruising, and non-classified severe thrombocytopenia $(<20,000 / \mu \mathrm{l})$ since infancy. Before tooth extractions and in case of severe bleeding he had received
Table 1. Published mutations in GPIX

\begin{tabular}{llll}
\hline $\begin{array}{l}\text { Missense } \\
\text { mutations }\end{array}$ & $\begin{array}{l}\text { Nonsense } \\
\text { mutations }\end{array}$ & Deletions & References \\
\hline & & $\begin{array}{l}\text { g.1644_1654del11 } \\
(\text { r.(-4)_7del) }\end{array}$ & this study \\
p.L(-10)P & & & {$[21]$} \\
p.C8R & & & {$[22]$} \\
p.D21G & & & {$[23]$} \\
p.L40P & & & {$[24]$} \\
p.N45S & & & {$[10,13,23,25-31]$} \\
p.F55S & & p.D86_P89delinsA & {$[32-34]$} \\
p.C73Y & & & {$[35]$} \\
& & & {$[36]$} \\
p.C97Y & & & {$[6,37-39]$} \\
& p.W127X & & {$[40]$} \\
p.A140T & p.W134X & & {$[41-43]$} \\
\hline
\end{tabular}

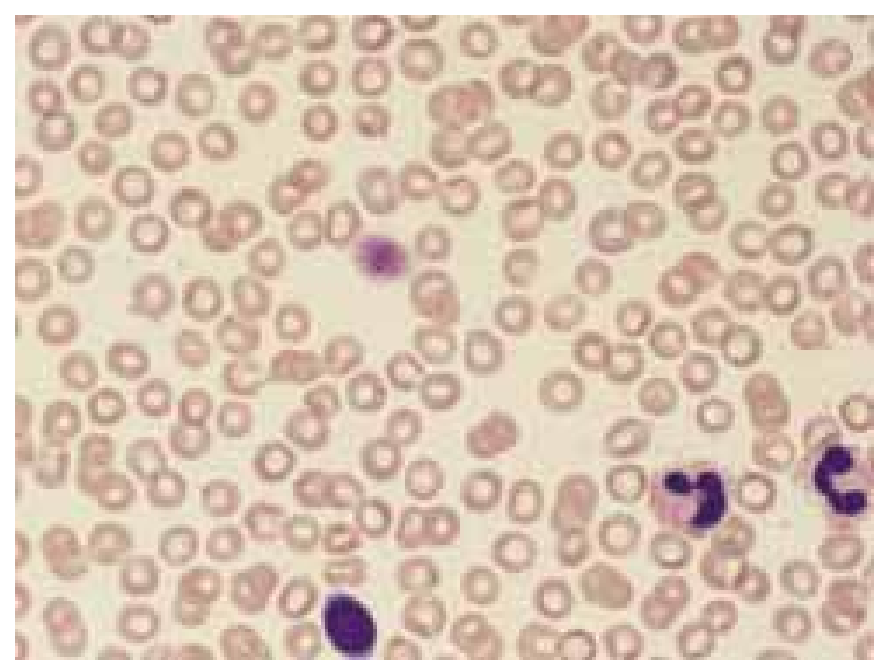

Fig. 1. Blood smear of the patient: giant platelet is detectable.

platelet and red blood cell transfusions at several occasions which led to the development of HLA and antiE antibodies. At the age of 39, the patient suffered from severe gastrointestinal bleeding at different sites leading to admission to the University Hospital Dresden. He required massive blood transfusions, ligature of the gastroduodenal artery, duodenotomy, and partial gastrectomy (Billroth-I resection), which finally led to a stop of the bleeding. Because of severe thrombocytopenia and the detection of giant platelets in the blood smear (fig. 1), BSS was suspected and flow cytometry analysis was initiated confirming the diagnosis of BSS. The presence of hereditary macrothrombocytopenia caused by a defect of non-muscle myosin type IIA, such as May-Hegglin anomaly, Sebastian platelet syndrome, and Fechtner syndrome, was ruled out by immunofluorescence staining. Extended coagulation diagnostics showed normal values for the global tests of hemostasis (prothrombin time, activated partial thromboplastin time (aPTT)), fibrinogen, coagulation factors VIII and XIII, VWF antigen, and collagen binding activity. Concerning the family history, the patient reported about the suspected diagnosis of chronic immune thrombocytopenia in his sister. She died at the age of 5 years most probably caused by serious perioperative bleeding after splenectomy. No bleeding diathesis was observed in the patient's parents and the patient's 2 daughters. 
Table 2. Flow cytometry analyses of the platelet GPIb/IX/V receptor

\begin{tabular}{|c|c|c|c|c|c|c|c|}
\hline \multirow[t]{2}{*}{ Parameter } & \multirow[t]{2}{*}{ Platelet count $\times 10^{9} / 1$} & \multicolumn{3}{|c|}{ MFI (arbitrary unit) } & \multicolumn{3}{|c|}{ Receptors per platelet } \\
\hline & & $\mathrm{CD} 42 \mathrm{a}$ & $\mathrm{CD} 42 \mathrm{~b}$ & $\mathrm{CD} 42 \mathrm{~d}$ & $\mathrm{CD} 42 \mathrm{a}$ & $\mathrm{CD} 42 \mathrm{~b}$ & $\mathrm{CD} 42 \mathrm{~d}$ \\
\hline Patient & 14 & 1.10 & 0.63 & 1.01 & 600 & 0 & 400 \\
\hline Daughter 1 & 266 & 18.1 & 14.5 & 7.77 & 34,100 & 27,100 & 14,000 \\
\hline Daughter 2 & 326 & 17.1 & 12.9 & 7.29 & 32,200 & 24,100 & 13,200 \\
\hline Control & 254 & 56.6 & 49.0 & 20.0 & 37,800 & 43,800 & 14,800 \\
\hline Normal range & $150-400$ & & & & $27,000-49,000$ & $20,000-32,000$ & $8,000-16,000$ \\
\hline
\end{tabular}

MFI = Mean fluorescence intensity.

Flow Cytometry Analyses

Flow cytometry analyses were performed using the ADIAflo ${ }^{\text {TM }}$ PLATELET GPIb/IX/V Kit (American Diagnostica GmbH, Pfungstadt, Germany) according to the manufacturer's recommendations. Platelet surface exposure of GPIb $\alpha$ (CD42b), GPIX (CD42a), and GPV (CD42d) was measured at the resting state using monoclonal antibodies (CD42b clone SZ2; CD42a clone SZ1; CD42d clone SW16).

Immunofluorescence Microscopy

Platelet immunofluorescence analysis with monoclonal antibodies against GPIX (CD42a), GPIIb/IIIa, GPIa, and non-muscle myosin IIa was performed as described before $[11,12]$.

Isolation and Amplification of Genomic DNA

Genomic DNA was isolated from EDTA blood using the DNA Kit from Qiagen (Qiagen GmbH, Hilden, Germany). All exons of the genes encoding $G P I b \alpha, G P I b \beta$ and $G P I X$ were amplified by polymerase chain reaction using intronic primers. The amplification was carried out under conditions described previously [13]. Purified DNA fragments were directly sequenced. The oligonucleotides used to amplify a 353-bp fragment encompassing exon 2 and 3 of the GPIX gene (accession no. M80478) were 5'-TTTCCCAGAGGAGAAGGCTG-3' (forward) and 5'-ACGGACTGAAGGCTGTTGTTG-3' (reverse).

\section{Results}

\section{Blood}

The platelet count revealed severe thrombocytopenia with $8,000-21,000$ platelets/ $\mu \mathrm{l}$, and the mean platelet volume was determined as $>12 \mathrm{fl}$. The blood smear demonstrated giant platelets. Platelet aggregometry was not possible because of the severe thrombocytopenia.

\section{Analyses of the Platelet GPIb/IX/V Receptor and von Willebrand Factor}

In contrast to a healthy platelet donor, there was no surface expression of GPIb/IX/V measurable on the patient's platelets (table 2). The mean fluorescence intensity (MFI) measured with CD42a, CD42b and CD42d of the 2 daughters' platelets was slightly decreased compared to the healthy control. Platelet count and receptor counts per platelet were within the normal range. Von Willebrand syndrome was ruled out in the patient (normal values for VWF antigen, collagenbinding capacity, VWF multimeric analysis, and factor VIII activity).

\section{Immunofluorescence Analysis}

The patient's platelets showed very weak immunofluorescence staining with a GPIX antibody (indicating GPIX protein deficiency). Expression of the GPIIb/IIIa complex was normal. Aberrant accumulation of non-muscle myosin heavy chain (MYH9) in white blood cells, which is typical for MYH-9 disorders (May-Hegglin anomaly or Sebastian platelet syndrome), was not detected.

\section{Sequencing Analysis}

A novel homozygous 11-nucleotide deletion (TCCCATGCCTG) starting at position 1644 in exon 3 of the GPIX gene (g.1644_1654del11) was identified in the patient's DNA (fig. 2). Sequencing results of the GPIb $\alpha$ and $G P I b \beta$ genes showed no difference compared to the public data base sequences. This genetic defect of GPIX leads to a deletion of the last 4 nucleotides of the Kozak sequence, the start codon, and the following 4 nucleotides of the coding sequence.

\section{Discussion}

In this study, we report on a novel genetic alteration of the GPIX gene (g.1644_1654del11) in a patient with a typical clinical phenotype of Bernard-Soulier syndrome (BSS). The patient suffered from recurrent epistaxis since infancy. Because of severe gastrointestinal bleeding requiring blood transfusions, a Billroth-I resection was performed. Evaluation of the peripheral blood smear revealed giant platelets. As other inherited platelet disorders such as MYH-9 disorders (e.g. May-Hegglin anomaly and Sebastian syndrome) also show giant platelets, these diseases were ruled out because the patient's white blood cells did not show inclusion bodies in the blood smear. Using flow cytometry, no surface expression of all 3 subunits of the GPIb/IX/V complex (GPIb $\alpha$, GPIb $\beta$ and GPIX) was measurable on the patient's platelets. In addition, platelet immunofluorescence staining revealed a markedly decreased GPIX protein level indicating a GPIX gene defect.

The four subunits assembling to the GPIb/IX/V complex belong to the leucine-rich family of proteins and are exclusively expressed in platelets [9]. Lack of a single subunit 
Fig. 2. Molecular genetic analysis of GPIX. The patient's genomic DNA revealed a homozygous deletion of 11 nucleotides (g.1644_1654del11) at the beginning of exon 3 in the GPIX gene. sis was performed with forward (left) and reverse (right) primer, respectively. B The start codon is box. Exon-intron structure of the GPIX gene demonstrates the location of the deletion. The g.1644_1654del11 deletion (red) results in the loss of the last 4 nucleotides of the ics), the start codon (bold), and the following nucleotides of the coding sequence.
A Sequencing analymarked with a red Kozak sequence (ital-
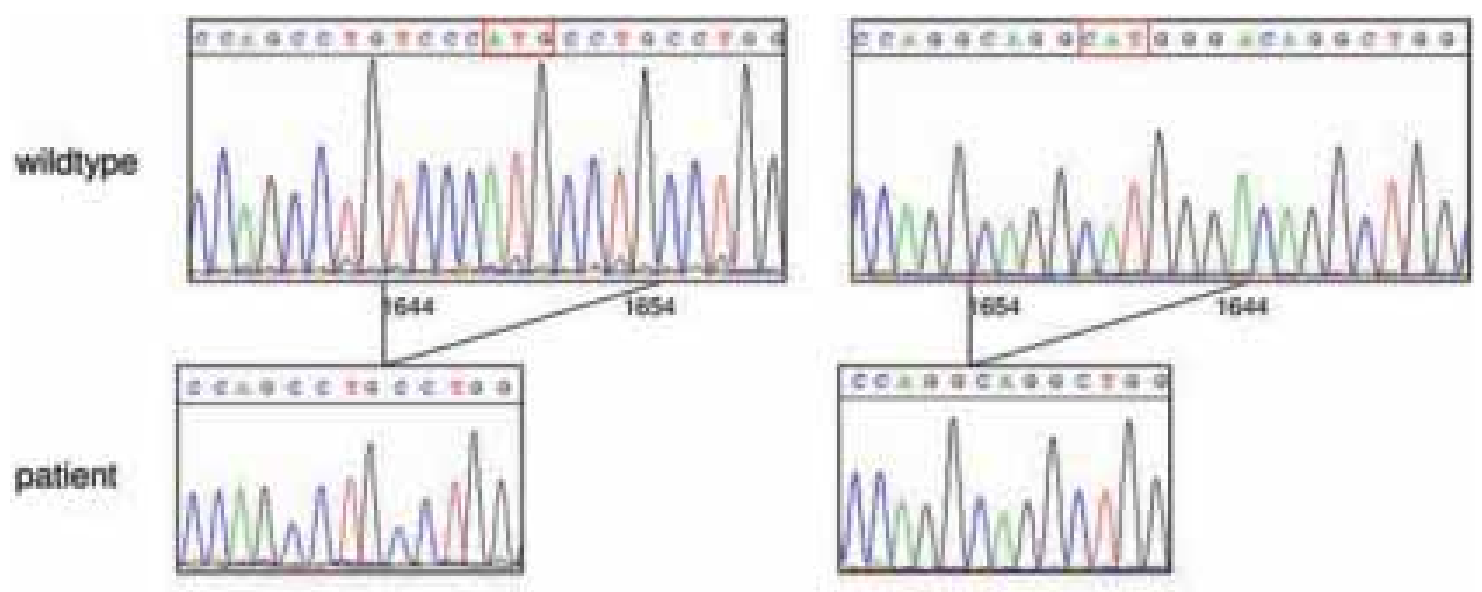

A

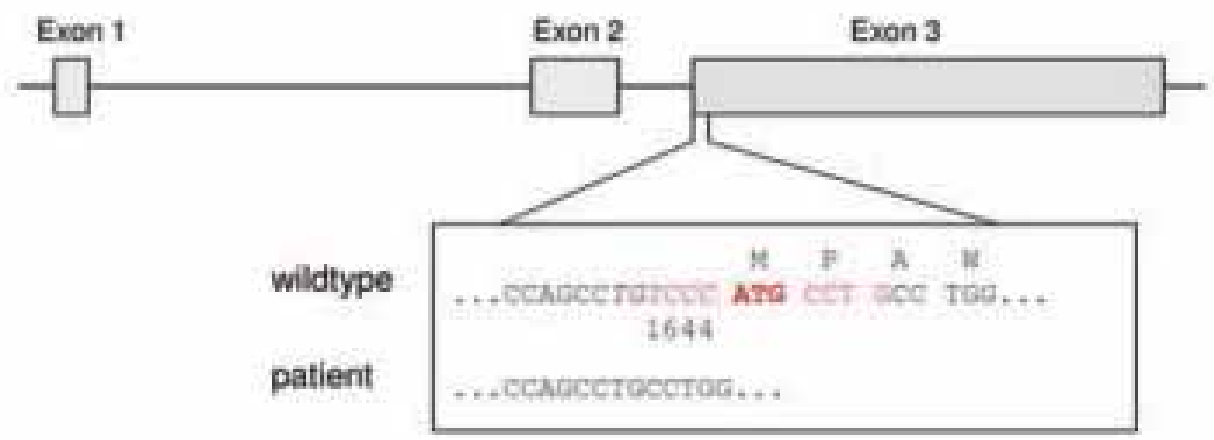

B

(GPIb $\alpha$, GPIb $\beta$, or GPIX) dramatically decreases surface expression of the whole complex. While most mutations were identified in the GPIb $\alpha$ gene, several mutations affecting the GPIX peptide have also been described in BSS patients. Almost all GPIX gene defects represent single nucleotide mutations within the coding sequence. Only 1 case with a 9-nucleotide deletion in the coding region of GPIX has been described [10]. This in-frame deletion resulted in the substitution of amino acid 86 (D86A) and deletion of amino acids 87-89. This female BSS patient was first investigated at the age of 6 years when she presented iron-deficiency anemia following recurrent epistaxis. She demonstrated prolonged bleeding from cuts and spontaneous bruising since early childhood. Laboratory tests showed low hemoglobin and ferritin levels, decreased platelet count, and giant platelets.

In the Caucasian patient described in this study, a novel 11-nucleotide deletion located at the junction of the 5'UTR (untranslated region) and the coding sequence of GPIX was identified. The start codon (methionine), the first 4 nucleotides of the coding sequence, and the last 4 nucleotides of the Kozak sequence are affected. The Kozak consensus sequence occurs on eukaryotic mRNA and is recognized by the ribosome as the translational start site [14]. The perfect Kozak sequence consists of gccRccAUGG with AUG as start codon, however, this site varies on different mRNAs in vivo (e.g. GPIX mRNA: tgtCccAUGC). Some nucleotides in this sequence are more important than others: the 'AUG' is essential since it is the actual initiation codon encoding a methionine amino acid at the $\mathrm{N}$-terminus of the protein. For a 'strong' consensus, the nucleotides at positions +4 (i.e. $G$ in the consensus) and -3 (i.e. either $A$ or $G$ in the consensus) must both match the consensus. An 'adequate' consensus has only 1 of these sites, while a 'weak' consensus has neither. The cc at positions -1 and -2 are not conserved but contribute to the overall strength [15].

Investigating the literature for Kozak sequence mutations/ deletions revealed a $-1 \mathrm{C}>\mathrm{T}$ mutation in the $\alpha$-tocopherol transfer protein ( $\alpha$-TTP) gene causing a decreased level of $\alpha$-TTP expression in a patient with ataxia with vitamin $\mathrm{E}$ deficiency [16]. In highly aggressive sporadic breast cancer, a $\mathrm{G}>\mathrm{C}$ mutation in $B R C A 1$ at position -3 was identified [17]. Here, the translation efficiency was markedly reduced. Afshar-Kharghan et al. [18] described a Kozak sequence polymorphism in GPIb $\alpha$, which is based on the presence of either thymine or cytosine at position -5 . The less common allele, $-5 \mathrm{C}$, is associated with a more efficient translation of GPIb $\alpha$ mRNA leading to increased expression of the GPIb/IX/V receptor on the cell membrane [19]. 
In the lamin $\mathrm{AC}(L M N A)$ gene, a 2-exon deletion causing a distinct highly malignant cardiomyopathy was identified [20]. This deletion affects the start codon-containing exon and an adjacent non-coding exon leading to decreased expression of lamin A and C. In addition, they postulate new potential translation initiation sites resulting in smaller proteins lacking the N-terminal region.

In this study, we identified a deletion within exon 3 of GPIX, including the start codon and the Kozak sequence, which has not been described before. As the Kozak sequence together with the start codon is indispensable for initiating the protein translation process, we postulate that the deletion of this region in GPIX severely affects GPIX protein synthesis. By scanning the GPIX amino acid sequence, we found one additional methionine at position 32. This codon may constitute a new potential translation initiation site demonstrating a strong Kozak consensus (gaaAccAUGG). In this case, GPIX protein synthesis of a N-terminal truncated GPIX protein lacking the signal peptide (aa 1-16) and the first 15 amino acids of the extracellular domain (aa 17-147) will occur. Because the signal peptide is essential for the translation of transmembrane/extracellular proteins, its absence will prevent protein translocation to the cell membrane, which may lead to degradation. Accordingly, immunofluorescence analy- sis of patient's platelets revealed GPIX deficiency by using a GPIX antibody. Within the N-terminal part of GPIX, two different single amino acid substitutions were described causing BSS, one in the signal peptide [21] and one at amino acid 8 [22], both leading to the absence of the GPIb/IX/V complex at the platelet surface. We conclude that the GPIX deletion in the described patient prevents proper formation of the GPIb/ IX/V complex. In conclusion, the identified 11-nucleotide deletion in the GPIX gene was identified as causative for the clinical picture of BSS. Interestingly, the patient was not diagnosed until he had reached the age of 39 years although bleeding symptoms such as recurrent epistaxis were present since infancy. Therefore, patients with recurrent mucocutaneous bleeding symptoms should be especially investigated for disorders of primary hemostasis.

\section{Acknowledgement}

The study was supported by CSL Behring, Hattersheim.

\section{Disclosure}

The authors declared no conflict of interest.

\section{References}

$>1$ Nurden P, Nurden AT: Congenital disorders associated with platelet dysfunctions. Thromb Haemost 2008;99:253-263.

2 Inoue O, Suzuki-Inoue K, Ozaki Y: Redundant mechanism of platelet adhesion to laminin and collagen under flow: involvement of von Willebrand factor and glycoprotein Ib-IX-V. J Biol Chem 2008; 283:16279-16282.

3 Simon D, Kunicki T, Nugent D: Platelet function defects. Haemophilia 2008;14:1240-1249.

4 Pham A, Wang J: Bernard-Soulier syndrome: an inherited platelet disorder. Arch Pathol Lab Med 2007;131:1834-1836.

5 Kunishima S, Kamiya T, Saito H: Genetic abnormalities of Bernard-Soulier syndrome. Int J Hematol 2002;76:319-327.

6 Kunishima S, Saito H: Congenital macrothrombocytopenias. Blood Rev 2006;20:111-121.

7 Berndt MC, Shen Y, Dopheide SM, Gardiner EE, Andrews RK: The vascular biology of the glycoprotein Ib-IX-V complex. Thromb Haemost 2001; 86:178-188.

$>$ Lopez JA, Andrews RK, Afshar-Kharghan V, Berndt MC: Bernard-Soulier syndrome. Blood 1998;91:4397-4418.

- Lanza F: Bernard-Soulier syndrome (hemorrhagiparous thrombocytic dystrophy). Orphanet J Rare Dis 2006;1:46.

10 Drouin J, Carson NL, Laneuville O: Compound heterozygosity for a novel nine-nucleotide deletion and the Asn45Ser missense mutation in the glycoprotein IX gene in a patient with Bernard-Soulier syndrome. Am J Hematol 2005;78:41-48.
11 Jedlitschky G, Cattaneo M, Lubenow LE, Rosskopf D, Lecchi A, Artoni A, Motta G, Niessen J, Kroemer HK, Greinacher A: Role of MRP4 (ABCC4) in platelet adenine nucleotide-storage: evidence from patients with delta-storage pool deficiencies. Am J Pathol 2010;176:1097-1103.

12 Jedlitschky G, Tirschmann K, Lubenow LE, Nieuwenhuis HK, Akkerman JW, Greinacher A, Kroemer HK: The nucleotide transporter MRP4 (ABCC4) is highly expressed in human platelets and present in dense granules, indicating a role in mediator storage. Blood 2004;104:3603-3610.

13 Zieger B, Jenny A, Tsakiris DA, Bartsch I, Sandrock K, Schubart C, Schafer S, Busse A, Wuillemin WA: A large Swiss family with Bernard-Soulier syndrome - correlation phenotype and genotype. Hamostaseologie 2009;29:161-167.

14 Kozak M: An analysis of 5'-noncoding sequences from 699 vertebrate messenger RNAs. Nucleic Acids Res 1987;15:8125-8148.

15 Kozak M: Point mutations define a sequence flanking the AUG initiator codon that modulates translation by eukaryotic ribosomes. Cell 1986;44:283292.

16 Usuki F, Maruyama K: Ataxia caused by mutations in the alpha-tocopherol transfer protein gene. J Neurol Neurosurg Psychiatry 2000;69:254-256.

17 Signori E, Bagni C, Papa S, Primerano B, Rinaldi M, Amaldi F, Fazio VM: A somatic mutation in the 5'UTR of BRCA1 gene in sporadic breast cancer causes down-modulation of translation efficiency. Oncogene 2001;20:4596-4600.
8 Afshar-Kharghan V, Li CQ, Khoshnevis-Asl M, Lopez JA: Kozak sequence polymorphism of the glycoprotein (GP) Ibalpha gene is a major determinant of the plasma membrane levels of the platelet GP Ib-IX-V complex. Blood 1999;94:186-191.

19 Meisel C, Afshar-Kharghan V, Cascorbi I, Laule M, Stangl V, Felix SB, Baumann G, Lopez JA, Roots I, Stangl K: Role of Kozak sequence polymorphism of platelet glycoprotein Ibalpha as a risk factor for coronary artery disease and catheter interventions. J Am Coll Cardiol 2001;38:1023-1027.

20 Van Tintelen JP, Tio RA, Kerstjens-Frederikse WS, van Berlo JH, Boven LG, Suurmeijer AJ, White SJ, den Dunnen JT, te Meerman GJ, Vos YJ, van der Hout AH, Osinga J, van den Berg MP van Veldhuisen DJ, Buys CH, Hofstra RM, Pinto YM: Severe myocardial fibrosis caused by a deletion of the 5' end of the lamin A/C gene. J Am Coll Cardiol 2007:49:2430-2439.

21 Lanza F, De La Salle C, Baas MJ, Schwartz A, Boval B, Cazenave JP, Caen JP: A Leu7Pro mutation in the signal peptide of platelet glycoprotein (GP)IX in a case of Bernard-Soulier syndrome abolishes surface expression of the GPIb-V-IX complex. Br J Haematol 2002;118:260-266.

22 Rivera CE, Villagra J, Riordan M, Williams S, Lindstrom KJ, Rick ME: Identification of a new mutation in platelet glycoprotein IX (GPIX) in a patient with Bernard-Soulier syndrome. Br J Haematol 2001;112:105-108

23 Wright SD, Michaelides K, Johnson DJ, West NC, Tuddenham EG: Double heterozygosity for mutations in the platelet glycoprotein IX gene in three siblings with Bernard-Soulier syndrome. Blood 1993;81:2339-2347. 
24 Noris P, Arbustini E, Spedini P, Belletti S, Balduini CL: A new variant of Bernard-Soulier syndrome characterized by dysfunctional glycoprotein (GP) Ib and severely reduced amounts of GPIX and GPV. Br J Haematol 1998;103:10041013.

25 Clemetson JM, Kyrle PA, Brenner B, Clemetson KJ: Variant Bernard-Soulier syndrome associated with a homozygous mutation in the leucine-rich domain of glycoprotein IX. Blood 1994;84:1124-1131.

26 Donnér M, Karpman D, Kristoffersson AC, Winqvist I, Holmberg L: Recurrent mutation Asn45-->Ser of glycoprotein IX in Bernard-Soulier syndrome. Eur J Haematol 1996;57:178-179.

27 Koskela S, Javela K, Jouppila J, Juvonen E, Nyblom O, Partanen J, Kekomäki R: Variant Bernard-Soulier syndrome due to homozygous Asn45Ser mutation in the platelet glycoprotein (GP) IX in seven patients of five unrelated Finnish families. Eur J Haematol 1999;62:256-264.

28 Vanhoorelbeke K, Schlammadinger A, Delville JP, Handsaeme J, Vandecasteele G, Vauterin S, Pradier O, Wijns W, Deckmyn H: Occurrence of the Asn45Ser mutation in the GPIX gene in a Belgian patient with Bernard Soulier syndrome. Platelets 2001;12:114-120.

29 Sachs UJ, Kroll H, Matzdorff AC, Berghöfer H, Löpez JA, Santoso S: BernardSoulier syndrome due to the homozygous Asn-45Ser mutation in GPIX: an unexpected, frequent finding in Germany. Br J Haematol 2003;123:127-131.

-30 Liang HP, Morel-Kopp MC, Clemetson JM, Clemetson KJ, Kekomaki R, Kroll H, Michaelides K, Tuddenham EG, Vanhoorelbeke K, Ward CM: A common ancestral glycoprotein (GP) 9 1828A $>\mathrm{G}$ (Asn45Ser) gene mutation occurring in European families from Australia and Northern Europe with Bernard-Soulier syndrome (BSS). Thromb Haemost 2005;94:599-605.

31 Dağistan N, Kunishima S: First Turkish case of Bernard-Soulier syndrome associated with GPIX N45S. Acta Haematol 2007;118:146-148.

32 Noris P, Simsek S, Stibbe J, von dem Borne AE: A phenylalanine-55 to serine amino-acid substitution in the human glycoprotein IX leucine-rich repeat is associated with Bernard-Soulier syndrome. Br J Haematol 1997;97:312-320.

-33 Suzuki K, Hayashi T, Yahagi A, Akiba J, Tajima K, Satoh S, Sasaki H: Novel point mutation in the leucine-rich motif of the platelet glycoprotein IX associated with Bernard-Soulier syndrome. Br J Haematol 1997;99:794-800.

-34 Afrasiabi A, Lecchi A, Artoni A, Karimi M, Ashouri E, Peyvandi F, Mannucci PM: Genetic characterization of patients with Bernard-Soulier syndrome and their relatives from Southern Iran. Platelets 2007;18:409-413.

35 Noda M, Fujimura K, Takafuta T, Shimomura T, Fujii T, Katsutani S, Fujimoto T, Kuramoto A, Yamazaki T, Mochizuki T, Matsuzaki M, Sano M: A point mutation in glycoprotein IX coding sequence (Cys73 (TGT) to Tyr(TAT)) cause impaired surface expression of GPIb/IX/V complex in two families with Bernard-Soulier syndrome. Thromb Haemost 1996;76:874-878.

36 Kunishima S, Tomiyama Y, Honda S, Kurata Y, Kamiya T, Ozawa K, Saito H Cys97-->Tyr mutation in the glycoprotein IX gene associated with BernardSoulier syndrome. Br J Haematol 1999;107:539-545.

\$37 Noda M, Fujimura K, Takafuta T, Shimomura T, Fujimoto T, Yamamoto N, Tanoue K, Arai M, Suehiro A, Kakishita E, et al: Heterogeneous expression of glycoprotein Ib, IX and V in platelets from two patients with BernardSoulier syndrome caused by different genetic abnormalities. Thromb Haemost 1995;74:1411-1145.

- 38 Iwanaga M, Kunishima S, Ikeda S, Tomonaga M, Naoe T: Vulnerable mutation Trp126-->stop of glycoprotein IX in Japanese Bernard-Soulier syndrome. Eur J Haematol 1998;60:264-266.

39 Toyohama T, Nagasaki A, Gushi K, Tamaki K, Masuda M, Takasu N: Recurrent mutation Trp126 --> stop of glycoprotein IX in Japanese Bernard-Soulier syndrome. Platelets 2003;14:197-198.

40 Xu LM, Sun GB, Wang P, Sun N, Hu QP, Cao FF, Peng B, Zhang DH: Single novel mutation in transmembrane region of glycoprotein (GP) IX affects GP Ib-IX complex expression and causes Bernard-Soulier syndrome. Br J Haematol 2010;150:627-629.

41 Wang Z, Shi J, Han Y: A novel point mutation in the transmembrane domain of platelet glycoprotein IX gene identified in a Bernard-Soulier syndrome patient (in Chinese). Zhonghua Xue Ye Xue Za Zhi 2001;22:464-466.

42 Wang Z, Zhao X, Duan W, Fu J, Lu M, Wang G, Bai X, Ruan C: A novel mutation in the transmembrane region of glyco-protein IX associated with BernardSoulier syndrome. Thromb Haemost 2004;92:606-613.

43 Garner C, Best S, Menzel S, Rooks H, Spector TD, Thein SL: Two candidate genes for low platelet count identified in an Asian Indian kindred by genome-wide linkage analysis: glycoprotein IX and thrombopoietin. Eur J Hum Genet 2006;14: 101-108. 